\title{
Effect of Magnesium Deficiency on Blood Pressure in Normal Rats Fed Cadmium
}

\author{
Shoji Nishiyama, ${ }^{*, a, 1}$ Satomi Onosaka, ${ }^{b}$ Noboru Saito, ${ }^{c}$ Yuko Konishi, ${ }^{d}$ and Toshio Nakadate ${ }^{a}$ \\ ${ }^{a}$ Department of Hygiene and Preventive Medicine, School of Medicine, Showa University, 1-5-8 Hatanodai, Shinagawa, Tokyo 142- \\ 8555, Japan, ${ }^{b}$ Faculty of Nutrition, Kobe-Gakuin University, Ikawadani-cho, Nishi-ku, Kobe 651-2180, Japan, 'Department of Inter- \\ nal Medicine and Center for Lifestyle-related Disease, Miyazaki Medical Center Hospital, 2-16, Takamatsucho, Miyazaki 880-0003, \\ Japan, and ${ }^{d}$ Medical Research Center, Department of Medicine, Kochi University, Kohasu, Oko, Nankoku, Kochi 783-8505, Japan
}

(Received January 5, 2005; Accepted April 11, 2005)

\begin{abstract}
We attempted to further define the effects of an Mg-deficient diet on blood pressure in rats fed $\mathrm{Cd}$ for long periods. Twenty male Wistar rats were grouped according to four different diets: normal diet ( $\mathrm{N}$ rats); normal diet supplemented with $\mathrm{Cd}$ at a dose of $50 \mu \mathrm{g} / \mathrm{g}$ of diet ( $\mathrm{N}$ rats fed $\mathrm{Cd}$ ); $\mathrm{Mg}$-deficient diet (D rats); and Mg-deficient diet supplemented with $\mathrm{Cd}$ at a dose of $50 \mu \mathrm{g} / \mathrm{g}$ of diet (D rats fed Cd). Each diet was given for 60 days. $\mathrm{N}$ rats fed $\mathrm{Cd}$ developed a duration-limited increase in blood pressure: by day 60 , increased blood pressure returned to the level seen in $\mathrm{N}$ rats. $\mathrm{Mg}$ deficiency lowered the Cd-induced increase in blood pressure and this response was more pronounced on day 60. A variety of independent blood pressure regulatory mechanisms was investigated. Although $\mathrm{Mg}$ deficiency tended to occur at lower concentrations of $\mathrm{Cd}$ and metallothionein in the heart of $\mathrm{N}$ rats fed $\mathrm{Cd}$ and the $\mathrm{Cd}$ concentration was less than $5 \mu \mathrm{g} / \mathrm{g}$ of tissue, $\mathrm{Mg}$ deficiency increased the Ca concentration in the hearts of $\mathrm{N}$ rats fed $\mathrm{Cd}$ while a decrease in urinary Na excretion and an increase in water retention were not observed. Diet-related toxic clinical signs in D rats fed Cd induced marked blush on the ears and fingers, indicating vasodilatation had occurred. These findings may have been a factor in the pronounced reduction in blood pressure seen.
\end{abstract}

Key words — cadmium, blood pressure, magnesium, deficiency, calcium

\section{INTRODUCTION}

Some epidemiological studies have reported that high cadmium $(\mathrm{Cd})$ concentrations are associated with a rise in blood pressure, and that this rise is particularly pronounced in subjects with hypertensive disease. ${ }^{1,2)}$ However, other epidemiological studies in Belgium produced evidence inconsistent with the hypothesis that environmental exposure to $\mathrm{Cd}$ leads to an increase in blood pressure and a higher prevalence of hypertension., ${ }^{3,4)}$ Although many reports have shown an increase in blood pressure in experimental animals treated parentally with $\mathrm{Cd}$, 5,6) the effects of dietary administration of $\mathrm{Cd}$ over long

\footnotetext{
${ }^{1}$ Present address: Project Planning and Development Pharmaceuticals, Meiji Seika Kaisha, Ltd., 2-4-16, Kyobashi, Chuo, Tokyo 104-8002, Japan

*To whom correspondence should be addressed: Project Planning and Development Pharmaceuticals, Meiji Seika Kaisha, Ltd., 2-4-16, Kyobashi, Chuo, Tokyo 104-8002, Japan. Tel.: +81-3-3273-3437; Fax: +81-3-3273-3439; E-mail: shoji_nishiyama@meiji.co.jp
}

periods and at low levels on blood pressure remain unknown.

Some workers have suggested that there is a relationship between magnesium $(\mathrm{Mg})$ intake and the incidences of increased blood pressure. ${ }^{7,8}$ In experimental animals, the alteration of blood pressure has been observed in $\mathrm{Mg}$-deficient rats. $\left.{ }^{9}, 10\right)$

These reports have speculated that dietary $\mathrm{Cd}$ supplementation and $\mathrm{Mg}$ deprivation leads to synergistic or additive effects on blood pressure in experimental animals. The aim of the present study was to further define the effects of an Mg-deficient diet on blood pressure in rats fed $\mathrm{Cd}$ for long periods.

\section{MATERIALS AND METHODS}

Diets - The basal composition of the experimental diet is given in Table 1. The normal diet ( $\mathrm{N}$ diet) was supplemented with magnesium oxide $(\mathrm{MgO})$ at a rate of $0.8 \mathrm{~g}$ per $\mathrm{kg}$ of diet. The $\mathrm{Mg}$-deficient diet did not contain $\mathrm{MgO}$ (D diet). Cd was added to the 
Table 1. Composition of Purified Basal Diet

\begin{tabular}{|c|c|}
\hline Ingredients & Percentage in diet $(\%)$ \\
\hline Sucrose & 50.0 \\
\hline Casein & 20.0 \\
\hline Purified starch & 15.0 \\
\hline Cellulose & 5.0 \\
\hline Olive oil & 5.0 \\
\hline Vitamin $\operatorname{mix}^{a}$ ) & 1.0 \\
\hline Mineral mix $\left.{ }^{b}\right)$ & 3.5 \\
\hline DL-methionine & 0.3 \\
\hline Choline hydrochloride & 0.2 \\
\hline \multicolumn{2}{|c|}{$\begin{array}{l}\text { a) Vitamin per } 100 \mathrm{~g} \text { diet: thiamine } 100 \mathrm{mg} \text {, riboflavin } \\
150 \mathrm{mg} \text {, pyridoxine } \mathrm{HCl} 100 \mathrm{mg} \text {, nicotinamide } 1000 \mathrm{mg} \text {, D- } \\
\text { panthenate } 500 \mathrm{mg} \text {, folic acid } 50 \mathrm{mg} \text {, vitamine } \mathrm{B}_{12} 0.1 \mathrm{mg} \text {, vi- } \\
\text { tamin A } 2.5 \times 10^{5} \mathrm{IU} \text {, vitamin E } 100 \mathrm{mg} \text {, calciferol } 2 \times 10^{4} \mathrm{IU} \text {, } \\
\text { vitamin C } 3.7 \times 10^{3} \mathrm{mg} \text {. b) Minerals per } 100 \mathrm{~g} \text { diet: } \mathrm{NaCl} \\
7.4 \mathrm{~g}, \mathrm{~K}_{2} \mathrm{C}_{6} \mathrm{H}_{5} \mathrm{O}_{7} \cdot \mathrm{H}_{2} \mathrm{O} 22 \mathrm{~g}, \mathrm{~K}_{2} \mathrm{SO}_{4} 5.2 \mathrm{~g} \text {, CaHPO } 50 \mathrm{~g}, \mathrm{MgO} \\
2.4 \mathrm{~g}, \mathrm{FeC}_{6} \mathrm{H}_{5} \mathrm{O}_{7} \cdot 5 \mathrm{H}_{2} \mathrm{O} 0.6 \mathrm{~g}, \mathrm{MnCO}_{3} 0.35 \mathrm{~g}, \mathrm{CuCO}_{3} 30 \mathrm{mg} \text {, } \\
\mathrm{CrK}\left(\mathrm{SO}_{4}\right)_{2} \cdot 12 \mathrm{H}_{2} \mathrm{O} 55 \mathrm{mg}, \mathrm{CoCl}_{2} \cdot 6 \mathrm{H}_{2} \mathrm{O} 10 \mathrm{mg}, \mathrm{Kl} 1 \mathrm{mg}, \mathrm{ZnCO}_{3} \\
160 \mathrm{mg} \text {. }\end{array}$} \\
\hline
\end{tabular}

$\mathrm{N}$ and $\mathrm{D}$ diets at a concentration of $50 \mathrm{mg}$ per $\mathrm{kg}$ of diet as $\mathrm{CdCl}_{2}$, to give two more diets, the $\mathrm{N}+\mathrm{Cd}$ diet and $\mathrm{D}+\mathrm{Cd}$ diet. To minimize spillage the four different diets were prepared in solid form. The levels of $\mathrm{Cd}, \mathrm{Mg}$, calcium $(\mathrm{Ca})$, iron (Fe), zinc $(\mathrm{Zn})$, and copper $(\mathrm{Cu})$ in the four diets were determined by flame atomic absorption spectrophotometry, as previously reported. ${ }^{11)}$ The $\mathrm{Cd}^{2+}$ concentration in the $\mathrm{N}$ and $\mathrm{D}$ diets was less than $0.02 \mu \mathrm{g} / \mathrm{g}$ of diet, and that in the $\mathrm{N}+\mathrm{Cd}$ and $\mathrm{D}+\mathrm{Cd}$ diets was $50 \mu \mathrm{g} / \mathrm{g}$ of diet. The $\mathrm{Mg}^{2+}$ concentration in the $\mathrm{N}$ diet was $500 \mathrm{mg} / \mathrm{kg}$ of diet, and in the D diet it was $10 \mathrm{mg} / \mathrm{kg}$ diet. The $\mathrm{Ca}^{2+}$ concentration in the four diets was $1.2 \mathrm{~g} / \mathrm{kg}$ of diet. The $\mathrm{Zn}, \mathrm{Fe}, \mathrm{Cu}$, and phosphorus (P) concentrations in the basal experimental diet corresponded to those recommended by the American Institute of Nutrition (AIN-76). ${ }^{12)}$

Experimental Design — Eight-week-old male STD-Wistar rats with a mean weight of about $210 \mathrm{~g}$ were purchased from Nippon SLC Co. Ltd. (Shizuoka, Japan). Twenty animals were grouped according to the four different diets: rats fed the $\mathrm{N}$ diet ( $\mathrm{N}$ rats); rats fed the $\mathrm{N}$ diet supplemented with $\mathrm{Cd}(\mathrm{N}$ rats fed $\mathrm{Cd})$; rats fed the $\mathrm{Mg}$-deficient diet ( $\mathrm{D}$ rats); and rats fed the $\mathrm{D}$ diet supplemented with $\mathrm{Cd}$ (D rats fed Cd). The rats were placed in plastic cages with stainless-steel tops in groups of five. They were housed in a temperature- $\left(25^{\circ} \mathrm{C}\right)$ and light-controlled room (12 hr light), as previously reported. ${ }^{11)}$ Food and distilled water were provided ad libitum for the entire experimental period of 60 days. Body weights and food consumption were recorded on days -1 (before dietary $\mathrm{Cd}$ supplementation), 15, 30, 45, and 60.

Regional Blood Flow (RBF) — All the animals were anesthetized with pentobarbital- $\mathrm{Na}(50 \mathrm{mg} / \mathrm{kg}$, i.p.) on day 60. Regional blood flow (RBF) was determined by the method of Fujioka et al. ${ }^{13)}$ In brief, under anesthesia, catheters (PE-50) were inserted into the right carotid and right femoral arteries to measure the mean blood pressure and reference flow. Then the former tubing was advanced into the left ventricle, the location being confirmed by pressure tracing. A reference flow rate was required for measurement of RBF. Carbonized microspheres (NENTRAC, specific activity $9.7 \mathrm{Ci} / \mathrm{g}), 16 \pm 0.1 \mu \mathrm{m}$ in diameter and labeled with ${ }^{141} \mathrm{Ce}$, were suspended in physiological saline with $0.01 \%$ Tween 80 . The suspension $(0.25 \mathrm{ml})$, containing 80000 microspheres and corresponding to a $0.2-\mu \mathrm{Ci}$ source of radioactivity for ${ }^{141} \mathrm{Ce}$, was injected and a reference sample collected from the right femoral artery at a constant rate of $0.41 \mathrm{ml} / \mathrm{min}$ with a constant withdrawal Harvard pump (Holliston, MA, United States). The reference sample was transferred to a counting tube and then the collection syringe and arterial catheter were rinsed with physiological saline. This washing was added to the counting tube and the radioactivity in the sample and in the arterial catheter was measured.

Blood Pressure — Systolic blood pressure was measured with a programmed electro-sphygmomanometer system (Narco PE-300) in conscious rats between 0900 and 1200 after $10 \mathrm{~min}$ in a $30^{\circ} \mathrm{C}$ environment. The values were the averages of five consecutive measurements for each animal, as previously reported. ${ }^{11)}$ Systolic blood pressure was recorded by the tail-cuff method, using the above mentioned system, on days $-1,30,45$, and 60 .

Urinary Na Excretion and Water Retention The daily water intake and urine excretion in each group were measured in a metabolic cage. Percentage water retention was expressed according to the formula of Doyle et al. ${ }^{14)}$

Percent water retention $=$ water intake $(\mathrm{ml})-$ urine output $(\mathrm{ml}) /$ water intake $(\mathrm{ml}) \times 100 \%$.

Metal Concentrations in the Organs — The heart, abdominal aorta, kidney, and liver of each rat were removed on day 60 , weighed, and quickly frozen in liquid $\mathrm{N}_{2}$. The concentrations of $\mathrm{Ca}, \mathrm{Mg}$, and $\mathrm{Cd}$ in these organs were assayed by flame atomic absorp- 


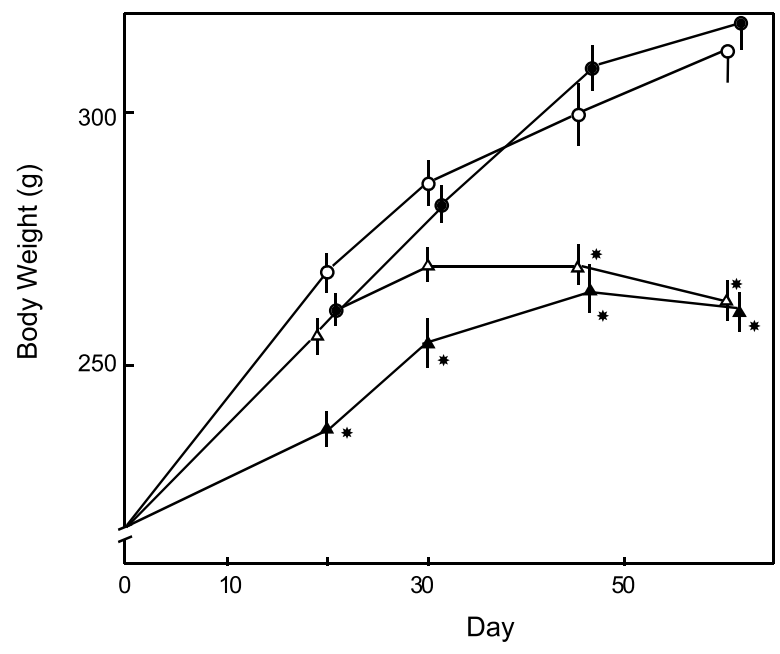

Fig. 1. Effect of an Mg-Deficient Diet on Body Weight Gain in Normal Rats Fed Cd

Symbols represent body weights of rats fed a normal diet $(\mathrm{O}), \mathrm{N}$ rats fed $\mathrm{Cd}(\bullet)$, D rats $(\triangle)$, and $\mathrm{D}$ rats fed $\mathrm{Cd}(\boldsymbol{\Delta})$. Each value is expressed as body weight $(\mathrm{g}) \pm$ S.E. of five animals. *Significantly different from normal rats at $p<0.05$, evaluated statistically by Bonferroni's test.

tion spectrophotometry. Cd concentrations in the heart, aorta, lung, kidney, and liver were assayed by flameless atomic absorption photometry (Hitachi polarized Zeeman atomic absorption spectrophotometer $180-80$ ), as previously reported. ${ }^{11)}$

Metallothionein Concentration - Metallothionein (MT) concentrations in the heart, lung, kidney, and liver were assayed by the method of Onosaka. ${ }^{15)}$ Statistical Analyses — All data were evaluated statistically by Bonferroni's test.

\section{RESULTS AND DISCUSSION}

Body weight gain in the $\mathrm{D}$ rats fed Cd decreased significantly from day 15 onwards when compared with those of $\mathrm{N}$ rats and $\mathrm{N}$ rats fed $\mathrm{Cd}$ (Fig. 1). However, no significant difference in food consumption in any of the four groups was found during the experimental period (data not shown). The diet-related toxic clinical sign observed in D rats fed Cd but not $\mathrm{N}$ rats was marked blush on the ears and fingers.

Dietary intake of $\mathrm{Cd}$ produced an increase in blood pressure in $\mathrm{N}$ rats at a limited term and dose, because blood pressure in the $\mathrm{N}$ rats fed $\mathrm{Cd}$ was elevated on days 30 and 45 but had returned to normal by day 60 (Fig. 2). Our previous study showed that parental administration of $\mathrm{Cd}$ at a dose of $1 \mathrm{mg} /$ $\mathrm{kg}$ of body weight in rats lowered blood pressure, whereas a dose of $0.5 \mathrm{mg} \mathrm{Cd} / \mathrm{kg}$ of body weight in-

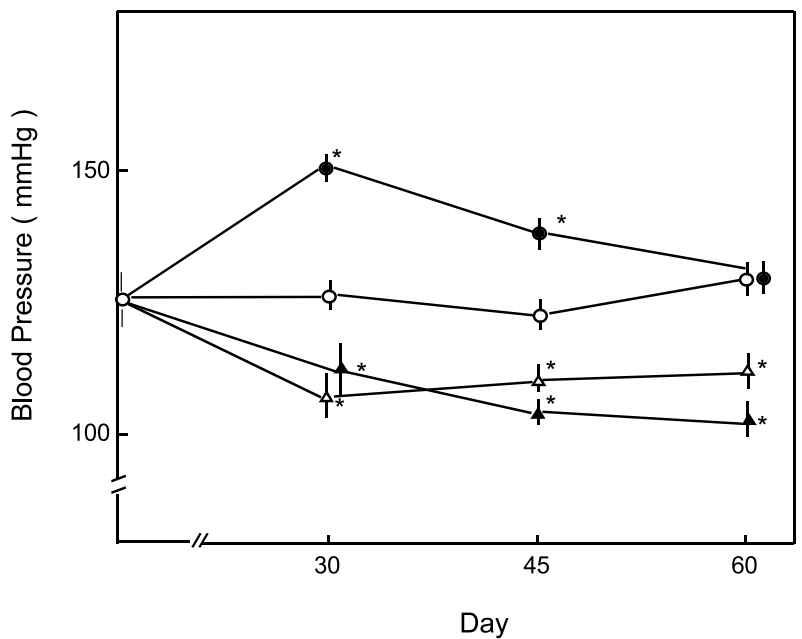

Fig. 2. Effect of an Mg-Deficient Diet on Blood Pressure in Normal Rats Fed Cd

Symbols represent blood pressures of rats fed a normal diet $(O), \mathrm{N}$ rats fed $\mathrm{Cd}(\bullet)$, D rats $(\triangle)$, and D rats fed $\mathrm{Cd}(\boldsymbol{\Delta})$. Each value is expressed as blood pressure $(\mathrm{mm} \mathrm{Hg}) \pm$ S.E. of five animals. *Significantly different from normal rats at $p<0.05$, evaluated statistically by Bonferroni's test.

creased blood pressure. ${ }^{11)}$ These results suggest that in rats treatment with $\mathrm{Cd}$ at lower doses induces hypertension, whereas treatment at higher doses induces hypotension.

$\mathrm{Mg}$ deficiency lowered the increase in blood pressure on days 30 and 45 , and this response was more pronounced on day 60 (Fig. 2). The regulation of blood pressure is a complex process involving a variety of independent regulatory mechanisms such as $\mathrm{Ca}$ concentration, $\mathrm{RBF}$ in the heart and aorta, and water retention in the body, which play important roles in the regulation of blood pressure. $\mathrm{Cd}$ and MT concentrations in the heart, kidney and liver of D rats fed $\mathrm{Cd}$ tended to be lower compared to $\mathrm{N}$ rats fed $\mathrm{Cd}$, except for the $\mathrm{Cd}$ concentration in the kidney (Table 2). Some workers have observed cardiotoxicity in rats that had about $5 \mu \mathrm{g} / \mathrm{g} \mathrm{Cd}$ in their cardiac tissues. ${ }^{16)}$ Compared to the present study, this concentration is higher than that in the $\mathrm{N}$ rats fed $\mathrm{Cd}$ and $\mathrm{D}$ rats fed $\mathrm{Cd}$. These results indicate that cardiotoxicity may not occur in $\mathrm{N}$ rats fed $\mathrm{Cd}$ and $\mathrm{D}$ rats fed Cd. However, Jamall and Smith ${ }^{17)}$ suggested that the absolute $\mathrm{Cd}$ concentration in the heart may not be as critical to the development of cardiotoxicity as the concentration of $\mathrm{Cd}$ relative to the concentrations of $\mathrm{Se}$ and $\mathrm{Ca}$, and perhaps other essential trace elements, even though the Cd dose was less than $5 \mu \mathrm{g} / \mathrm{g}$. Myocardial calcification through $\mathrm{Ca}$ influx into cardiac myocytes may be an important mechanism of cardiac injury. ${ }^{18)} \mathrm{An}$ increase in the $\mathrm{Ca} / \mathrm{Mg}$ 
Table 2. Cd and MT Concentrations in Cd-Fed Rats, Mg-Deficient Rats and Mg-Deficient Rats Fed Cd on day 60

\begin{tabular}{lcccc}
\hline \hline Organ $(\mu$ g per g) & Normal & Cd-fed & Depleted Mg & Depleted Mg and Cd-fed \\
\hline Heart $(\mathrm{Cd})$ & $0.73 \pm 0.5$ & $3.0 \pm 0.45^{a}$ & $0.61 \pm 0.4$ & $1.9 \pm 0.9$ \\
Heart (MT) & $16.9 \pm 4.2$ & $22.1 \pm 7.9^{a}$ & $14.0 \pm 1.8$ & $14.2 \pm 2.0$ \\
Aorta (Cd) & $0.10 \pm 0.02$ & $0.21 \pm 0.03$ & $0.04 \pm 0.004$ & $0.16 \pm 0.03$ \\
Kidney (Cd) & $0.06 \pm 0.02$ & $10.8 \pm 1.6^{a}$ & $0.07 \pm 0.01$ & $12.9 \pm 1.8^{a}$ \\
Kidney (MT) & $28.7 \pm 6.2$ & $260 \pm 7.7^{a}$ & $49.3 \pm 11.4$ & $189 \pm 24.1^{a, b}$ \\
Liver (Cd) & $0.60 \pm 0.4$ & $11.5 \pm 1.1^{a}$ & $1.1 \pm 0.2$ & $8.1 \pm 0.9^{a}$ \\
Liver (MT) & $15.7 \pm 6.3$ & $164 \pm 31^{a}$ & $31.8 \pm 7.7$ & $126 \pm 12.3^{a}$ \\
\hline
\end{tabular}

Values are mean \pm S.E. in micrograms per wet tissue $(\mathrm{g})$ in rats $(n=5)$ fed one of the four different diets. $a)$ significantly different from normal group at $p<0.05$, evaluated by Bonferroni's test. $b$ ) significantly different from $\mathrm{N}$ rats fed Cd group at $p<0.05$, evaluated by Bonferroni's test. MT was not detected in the aorta in any group.

Table 3. $\mathrm{Ca}$ and Mg Concentrations in Cd-Fed Rats, Mg-Deficient Rats and Mg-Deficient Rats Fed Cd on day 60

\begin{tabular}{lcccccc}
\hline \hline Organ $(\mu$ g per g) & Normal & Cd-fed & Depleted Mg & Depleted Mg and Cd-fed \\
\hline Heart $(\mathrm{Ca})$ & $11.2 \pm 0.4$ & $10.5 \pm 0.5$ & $30.8 \pm 8.6^{a}$ & & $15.3 \pm$ & $\left.0.6^{a, b}\right)$ \\
Heart $(\mathrm{Mg})$ & $212 \pm 7$ & $219 \pm 5$ & $200 \pm 2$ & $219 \pm$ & \pm \\
Aorta $(\mathrm{Ca})$ & $78.3 \pm 4.4$ & $91.4 \pm 4.2$ & $66.4 \pm 5.6$ & $88.1 \pm 15.4$ \\
Aorta $(\mathrm{Mg})$ & $275 \pm 22$ & $289 \pm 28$ & $194 \pm 48$ & $225 \pm 25$ \\
Kidney $(\mathrm{Ca})$ & $19.2 \pm 1.0$ & $18.0 \pm 3.0$ & $\left.806.7 \pm 176^{a}\right)$ & $837.3 \pm 138^{a, b)}$ \\
Kidney $(\mathrm{Mg})$ & $224 \pm 12$ & $218 \pm 29$ & $200 \pm 9$ & $232 \pm 19$ \\
\hline
\end{tabular}

Values are mean \pm S.E. in micrograms per wet tissue $(\mathrm{g})$ in rats $(n=5)$ fed one of the four different diets. $a$ ) significantly different from normal group at $p<0.05$, evaluated by Bonferroni's test. $b$ ) significantly different from $\mathrm{N}$ rats fed Cd group at $p<0.05$, evaluated by Bonferroni's test.

Table 4. RBF in Cd-Fed Rats, Mg-Deficient Rats and Mg-Deficient Rats Fed Cd on day 60

\begin{tabular}{llccc}
\hline \hline Reginal blood flow (ml/g per min) & Normal & Cd-fed & Depleted Mg & Depleted Mg and Cd-fed \\
\hline Heart & $4.48 \pm 0.62$ & $4.67 \pm 0.72$ & $5.03 \pm 1.3$ & $3.30 \pm 0.69$ \\
Lung & $0.39 \pm 0.1$ & $0.33 \pm 0.09$ & $0.68 \pm 0.23$ & $0.42 \pm 0.29$ \\
Brain & $0.61 \pm 0.11$ & $0.41 \pm 0.04$ & $0.54 \pm 0.08$ & $0.43 \pm 0.04$ \\
Kidney & $5.80 \pm 0.7$ & $4.95 \pm 0.62$ & $2.76 \pm 0.68^{a}$ & $2.40 \pm 0.68^{a}$ \\
Liver & $0.24 \pm 0.05$ & $0.24 \pm 0.04$ & $0.39 \pm 0.07$ & $0.46 \pm 0.13$ \\
\hline
\end{tabular}

Values are mean \pm S.E. of $\mathrm{ml}$ per wet tissue (g) per min. in rats $(n=5)$ fed one of the four different diets. $a$ ) significantly different from normal group at $p<0.05$, evaluated by Bonferroni's test.

ratio in the heart produces myocardial necrosis, and a decrease in this ratio prevents the development of cardiac necrosis. In the present study, Mg deficiency increased the $\mathrm{Ca}$ concentration in the hearts of the $\mathrm{D}$ rats fed $\mathrm{Cd}$ compared with $\mathrm{N}$ rats fed $\mathrm{Cd}$ (Table 3 ). There were no significant differences in $\mathrm{Mg}$ concentration in the heart compared to $\mathrm{N}$ rats fed $\mathrm{Cd}$ and $\mathrm{N}$ rats while urinary $\mathrm{Mg}$ excretion in $\mathrm{D}$ rats and $\mathrm{D}$ rats fed $\mathrm{Cd}$ was decreased (44 and $80 \%$ of normal). We have already reported that $\mathrm{Cd}$ ameliorates histopathological changes due to Ca overload in the hearts of D rats but may also inhibit the release of $\mathrm{Ca}^{2+}$, which is a major determinant of the level of contractile force. ${ }^{18)}$ In the present study, Mg deficiency also markedly increased $\mathrm{Ca}$ concentration in the kidney of $\mathrm{D}$ rats fed $\mathrm{Cd}$, suggesting that severe $\mathrm{Mg}$ deficiency produced renal damage in $\mathrm{D}$ rats fed $\mathrm{Cd}$, which corresponds to a marked decrease in RBF of the kidney (Table 4). It is well known that chronic renal failure was induced by surgical 5/6 renal ablation and that these 5/6 nephrectomy (NTX) rats showed elevated blood pressure 12 weeks after surgery. ${ }^{19)}$ This NTX evidence supports our speculation that renal damage induced in $\mathrm{D}+\mathrm{Cd}$ rats may not contribute to the lower blood pressure. A decrease in urinary $\mathrm{Na}$ excretion and an increase in water re- 
tention, which are important factors for the regulation of blood pressure, were not observed in $\mathrm{D}$ rats fed $\mathrm{Cd}$ compared to $\mathrm{N}$ rats and $\mathrm{N}$ rats fed $\mathrm{Cd}$ (data not shown). The diet-related toxic clinical manifestation observed in D rats fed Cd was marked blush on the ears and fingers, indicating that vasodilatation had occurred, which may have been caused by an increase in plasma serotonin. ${ }^{20)}$

From these results, it is concluded Ca overload in the heart might be ascribed to myocardial toxicity and vasodilatation in $\mathrm{D}$ rats fed $\mathrm{Cd}$, which may be a factor for lowered blood pressure in these rats.

Acknowledgements We thank Professors Keiichi Tanaka and Hiroshi Yamamoto of Osaka University for their critical review of the manuscript.

\section{REFERENCES}

1) Luoma, P. V., Nayha, S., Pyy, L. and Hassi, J. (1995) Association of blood cadmium to the area of residence and hypertensive disease in Arctic Finland. Sci. Total Environ., 15, 571-575.

2) Tomera, J. F. and Harakal, C. (1997) Multiple linear regression analysis of blood pressure, hypertrophy, calcium and cadmium in hypertensive and non-hypertensive states. Food Chem. Toxicol., 35, 713-718.

3) Staessen, J. A., Buchet, J. P., Ginucchio, G., Lauwerys, R. R., Lijnen, P., Roels, H. and Fagard, R. (1996) Public health implications of environmental exposure to cadmium and lead: an overview of epidemiological studies in Belgium. Working Groups. J. Cardiovasc. Risk, 3, 26-41.

4) Staessen, J. A., Kuznetsova, T., Roels, H. A., Emelianov, D. and Fagard, R. (2000) Exposure to cadmium and conventional and ambulatory blood pressures in a prospective population study. Public Health and Environmental Exposure to Cadmium Study Group. Am. J. Hypertens., 13, 146-156.

5) Wang, S. J., Paek, D. M., Kim, R. H. and Cha, B. S. (2002) Variation of systolic blood pressure in rats exposed to cadmium and nickel. Environ. Res., 88, 116-119.

6) Puri, V. N. and Saha, S. (2003) Comparison of acute cardiovascular effects of cadmium and captopril in relation to oxidant and angiotensin converting enzyme activity in rats. Drug Chem. Toxicol., 26, 213218.

7) Ascherio, A., Hennekens, C., Willett, W. C., Sacks, F., Rosner, B. and Manson, J. (1996) Prospective study of nutritional factors, blood pressure, and hypertension among US women. Hypertension, 27,
1065-1072.

8) Witteman, J. C., Grobbee, D. E., Derkx, F. H., Bouillon, R., deBruijn, A. M. and Hoffman, A. (1994) Reduction of blood pressure with oral magnesium supplementation in women with mild to moderate hypertension. Am. J. Clin. Nutri., 60, 129-135.

9) Murasato, Y., Harada, Y., Ikeda, M., Nakashima, Y. and Hayashida, Y. (1999) Effect of magnesium deficiency on autonomic circulatory regulation in conscious rats. Hypertension, 34, 247-252.

10) Touyz, R. M. (2003) Role of magnesium in the pathogenesis of hypertension. Mol. Aspects Med., 24, 107-136.

11) Nishiyama, S., Nakamura, K. and Konishi, Y. (1986) Blood pressure and urinary sodium and potassium excretion in cadmium-treated male rats. Environ. Res., 40, 357-364.

12) American Institute of Nutrition (1977) Report of American Institute of Nutrition Ad Hoc Committee on Standards for Nutritional Studies. J. Nutr., 107, 1340-1348.

13) Fujioka, S., Tamaki, T., Fukui, K., Okahara, T. and Abe, Y. (1985) Effects of a synthetic human atrial natriuretic polypeptide on regional blood flow in rats. Eur. J. Pharmacol., 109, 301-304.

14) Doyle, J. J., Bernhoft, R. A. and Sandstead, H. H. (1975) The effects of a low level of dietary cadmium on blood pressure, ${ }^{24} \mathrm{Na},{ }^{42} \mathrm{~K}$, and water retention in growing rats. J. Lab. Clin. Med., 86, 57-63.

15) Onosaka, S., Min, K. S., Fukuhara, C., Tanaka, K., Tashiro, S., Shimizu, I., Furuta, M., Yasutomi, T., Kobayashi, K. and Yamamoto, K. (1986) Concentrations of metallothionein and metals in malignant and non-malignant tissues in human liver. Toxicology, 38, 261-268.

16) Kopp, S. J., Glonek, T., Perry, H. M., Jr., Erlanger, M. and Perry, E. F. (1982) Cardiovascular actions of cadmium at environmental exposure levels. Science, 217, 837-839.

17) Jamall, I. S. and Smith, J. C. (1985) Effect of cadmium on glutathione peroxidase, superoxide dismutase and lipid peroxidation in the rat heart: a possible mechanism of cadmium cardiotoxicity. Toxicol. Appl. Pharmacol., 80, 33-42.

18) Nishiyama, S., Saito, N., Konishi, Y., Abe, Y. and Kusumi, K. (1990) Cardiotoxicity in magnesiumdeficient rats fed cadmium. J. Nutr. Sci. Vitaminol. (Tokyo), 36, 33-44.

19) Porsti, I., Fan, M., Koobi, P., Jolma, P., Kalliovalkama, J., Vehmas, T. I., Helin, H., Holthofer, H., Mervaala, E., Nyman, T. and Tikkanen, I. (2004) High calcium diet down-regulates kidney angiotensin-converting enzyme in ex- 
perimental renal failure. Kidney Int., 66, 2155-2166.

20) Alfrey, A. C. (1985) Disorders of magnesium metabolism. In The Kidney, Physiology and Pathophysi- ology (Seldin, D. W. and Giebisch, G., Eds.), Raven Press, New York, pp. 1281-1295. 